\title{
Materno-Fetal Prognosis of Retro-Placental Hematoma at the Centre Hospitalier Universitaire Communautaire
}

\author{
N. R. Ngbale*, G. R. D. L. Kogboma-Wongo, A. Koirokpi, C. E. Gaunefet, G. D. Kossa Ko Ouakoua, \\ S. Ouapou, D. M. Callot, S. Matoulou-M'bala, A. Sepou
}

The Maternity of Centre Hospitalier Universitaire Communautaire, Bangui, Central African Republic

Email: ${ }^{\star}$ gbaler@yahoo.fr

How to cite this paper: Ngbale, N.R., Kogboma-Wongo, G.R.D.L., Koirokpi, A., Gaunefet, C.E., Kossa Ko Ouakoua, G.D., Ouapou, S., Callot, D.M., Matoulou-M’bala, S. and Sepou, A. (2020) Materno-Fetal Prognosis of Retro-Placental Hematoma at the Centre Hospitalier Universitaire Communautaire. Open Journal of Obstetrics and Gynecology, 10, 1351-1357.

https://doi.org/10.4236/ojog.2020.10100124

Received: August 31, 2020

Accepted: October 10, 2020

Published: October 13, 2020

Copyright $\odot 2020$ by author(s) and Scientific Research Publishing Inc. This work is licensed under the Creative Commons Attribution International License (CC BY 4.0).

http://creativecommons.org/licenses/by/4.0/ (c) (i) Open Access

\begin{abstract}
Introduction: The majority of pregnancies and births go off without incident even though they all present risks. Retro-placental hematoma (RPH) is an extreme obstetric emergency. The aim of our study was to assess the maternal-fetal prognosis of this pathology in our patients. Patients and Methods: This is a retrospective descriptive and analytical study over 5 years ranging from the period from January 1st, 2015 to December 31st, 2019. The study's population consisted of pregnant women, in the 3rd trimester, who were presented with the retro-placental hematoma during the pregnancy or childbirth and taken care of in the maternity ward of the Centre Hospitalier Universitaire Communautaire. Results: During our study period, we recorded 87 cases of retro-placental hematoma, and 40,763 deliveries. The frequency of retro-placental hematoma was $0.21 \%$ at delivery. The average maternal age was 26.4 years with extremes of 16 and 40 years. The parity's average was 3.8 with extremes of 1 and 13. The mean gestational age at the time of the onset of the accident was 35.9 amenorrhea weeks (AW) with extremes of 28 and $40 \mathrm{AW}$. We performed 4 cases of hysterectomy (4.5\%). We recorded 8 maternal deaths $(9.2 \%)$ and 60 newborn deaths (69\%). The causes of maternal death were dominated by afibrinogenemia $62.5 \%$, followed by renal failure in $25 \%$. Conclusion: Retro-placental hematoma is a serious pathology during the pregnancy.
\end{abstract}

\section{Keywords}

Prognosis, Retro-Placental Hematoma (RPH), Bangui 


\section{Introduction}

The majority of pregnancies and births go off without incident even though they all present risks [1]. Among these risks there is retro-placental hematoma (RPH), an extreme obstetric emergency. RPH, and placental insertion anomalies, are the two main etiologies of bleeding in the third trimester of pregnancy [2] [3]. RPH is a major cause of perinatal mortality and morbidity [4].

In general, $30 \%$ of HRP cases can be iatrogenic origin [2]. The proportion of $\mathrm{RPH}$ in the population is estimated at $0.8 \%, 0.7 \%$ and $1.0 \%$, respectively in all races, white and black [5]. But its frequency is variously appreciated. Globally, some authors estimate it to be $0.25 \%$ to $0.50 \%$ of cases on average [2]. In the USA, its incidence is estimated between $0.6 \%$ and $1.2 \%$ of all pregnancies [6]. In $80,000$ deliveries, 181 cases ( $0.23 \%)$ of RPH were observed by Merger [7]. In Africa, the Akpadza study in Togo estimated its frequency at $0.47 \%$ [8]. Other African authors have reported higher RPH frequencies ranging from $1.97 \%$ to 3.6\% [9] [10] [11].

In the Central African Republic (CAR), no specific study has been carried out on the subject. In the studies by Sépou and Coll on bleeding in the third trimester of pregnancy, $0.23 \%$ of RPH cases (17 cases/7164 deliveries) were observed [12]. In another Central African study, these bleedings are due to RPH in $0.16 \%$ of cases [13]. The proportions of maternal and neonatal deaths from RPH were $5.3 \%$ and $71.4 \%$, respectively [14]. Other studies report $1.2 \%$ and $6.2 \%$ respectively of maternal deaths from RPH [14] [15]. The purpose of our study was to assess the maternal-fetal prognosis of this pathology in our patients.

\section{Patients and Methods}

This is a retrospective descriptive and analytical study over 5 years ranging from the period from January 1st, 2015 to December 31st, 2019. The study population consisted of pregnant women, in the 3rd trimester who presented with the retro-placental hematoma during the pregnancy or childbirth and taken care in the maternity ward of the Centre Hospitalier Universitaire Communautaire. The RPH diagnosis was clinically done and confirmed after the childbirth. Our sample was comprehensive, including all retro-placental hematoma cases. The variables studied on each patient were: Age, parity, gestational age, history of toxemia of pregnancy, clinical signs, association with placenta previa, route of delivery and maternal-fetal complications.

The data were collected on a pre-established form, tested and validated during the pre-survey phase. After the analysis and coding of the survey forms, data entry and analysis were done with Epi Info software version 3.5.3. We received the ethical clearance before realizing the study.

\section{Results}

During our study period, we recorded 87 cases of retro-placental hematoma, and 40,763 deliveries. The frequency of retro-placental hematoma was $0.21 \%$ at deli- 
very. The average maternal age was 26.4 years with extremes of 16 and 40 years. The average parity was 3.8 with extremes of 1 and 13 (Table 1).

The mean gestational age at the time of the onset of the accident was 35.9 amenorrhea weeks (AW) with extremes of 28 and $40 \mathrm{AW}$. The majority of patients, 63 cases $(72.4 \%)$, were seen after $37 \mathrm{AW}$ while in $27.6 \%$ (24 cases) the gestational age ranged from 28 to $36 \mathrm{AW}$. The high blood pressure history on the pregnancy was found in $43 \%$ of the patients. Clinically $17.3 \%$ had altered consciousness, and $81.6 \%$ had conjunctival pallor (Table 2).

Table 1. Distribution according to the age and the parity of patients.

\begin{tabular}{ccc}
\hline Parameters & Rate $(\mathrm{n}=\mathbf{8 7})$ & Percentage \\
\hline Age & 12 & 13.8 \\
$15-19$ years old & 27 & 31 \\
$20-24$ years old & 22 & 25.3 \\
$25-29$ years old & 15 & 17.2 \\
$30-34$ years old & 11 & 12.7 \\
$\geq 35$ years old & & \\
Parity & 22 & 25.3 \\
Primiparous & 26 & 29.9 \\
Pauciparous & 19 & 21.8 \\
Multiparous & 20 & 23 \\
Bigmultiparous & $\mathbf{8 7}$ & $\mathbf{1 0 0}$ \\
Total & &
\end{tabular}

Table 2. Distribution according to the general signs.

\begin{tabular}{ccc}
\hline General signs & Workforce $(\mathbf{n}=\mathbf{8 7})$ & Percentage \\
\hline State of mind & 72 & 82.7 \\
Good & 15 & 17.3 \\
Altered & & \\
Conjunctiva & 71 & 81.6 \\
Pale & 16 & 18.4 \\
Normo-colored & & \\
Blood pressure $(B P)$ & 39 & 44.8 \\
SBP $\leq 90 \mathrm{~mm} \mathrm{Hg}$ & 31 & 35.6 \\
DBP $<90 \mathrm{~mm} \mathrm{Hg}$ and SBP $\geq 100 \mathrm{~mm} \mathrm{Hg}$ & 17 & 19.6 \\
DBP $\geq 90 \mathrm{~mm} \mathrm{Hg}$ & &
\end{tabular}

SBP $=$ Systolic Blood Pressure and DBP = Diastolic Blood Pressure. 
The combination of retro-placental hematoma and placenta previa was found in 5 patients (5.7\%). The diagnosis of retro-placental hematoma was clinical in 84 patients $(96.5 \%)$ compared to 3 cases (3.5\%) diagnosed after emergency ultrasound.

The proportion of vaginal deliveries was 45 cases (51.7\%), and caesarean section 42 cases $(48.3 \%)$. We performed 4 cases of hysterectomy (4.5\%). We recorded 8 maternal deaths (9.2\%) (Table 3) and 60 newborn deaths (69\%).

The causes of maternal death were dominated by afibrinogenemia $62.5 \%$, followed by renal failure in $25 \%$. Factors influencing maternal death were referred parturients and those who developed afibrinogenemia with a statistically significant difference (Table 4).

\section{Discussion}

We did a hospital study that cannot be extrapolated to the whole country. This is the limit of the study. The frequency of cases of retro-placental hematoma in our series was $0.21 \%$ of delivery. This frequency is similar to that of several authors who respectively reported $0.47 \%, 0.34 \%, 0.65 \%$, and $0.23 \%$ [8] [12] [16] [17].

This frequency follows the trend of high blood pressure during pregnancy. Patients in the 20 to 24 age group were found in $31 \%$ of cases in our study. This proportion is identical to that reported by Akpadza in Togo and Mezane in Morocco, with respectively $29.86 \%$ and $29.8 \%$ of cases [8] [18].

Table 3. Distribution according to the types of maternal complications.

\begin{tabular}{ccc}
\hline Complication & Workforce $(\mathbf{n}=\mathbf{8 7})$ & Percentage \\
\hline Death & 8 & 9.2 \\
Anemia & 71 & 41.6 \\
Hypovolemic Shock & 39 & 13.8 \\
Bleeding disorders & 12 & 5.7 \\
Acute renal Failure & 5 & 5.8 \\
\hline
\end{tabular}

Table 4. Distribution according to the admission mode and the causes of death.

\begin{tabular}{|c|c|c|c|c|c|}
\hline & \multicolumn{2}{|c|}{ Maternal Prognosis } & \multirow{2}{*}{ OR (IC at 95\%) } & \multirow{2}{*}{$\begin{array}{l}\mathrm{Chi}^{2} \text { of } \\
\text { Yates }\end{array}$} & \multirow{2}{*}{$\mathrm{p}$} \\
\hline & Death & Survival & & & \\
\hline \multicolumn{6}{|l|}{ Admission mode } \\
\hline Coming from home & 3 & 64 & $0.14[0.026-0.69]$ & \multirow[b]{2}{*}{5.5055} & \multirow[b]{2}{*}{0.018} \\
\hline Referred & 5 & 15 & 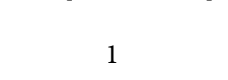 & & \\
\hline \multicolumn{6}{|l|}{ Causes of death } \\
\hline Afibrinogenemia & 5 & 7 & 9.18 [1.74 - 56.38] & \multirow[b]{2}{*}{6.72} & \multirow[b]{2}{*}{0.0095} \\
\hline Acute renal failure & 3 & 41 & 1 & & \\
\hline
\end{tabular}


Then, teenage girls had also occupied a significant place with $13.8 \%$ of cases. In Chad, Foumsou found $10.9 \%$ of HRP cases in obstetric complications in adolescent girls during labor [19]. The proportion of teenage girls found by Akpadza and Mezane is lower than that of our study, respectively 5.22\% and 8.5\% [8].

This is explained by the fact that girls enter sex life in Bangui at an early age, as Sépou has pointed out [20]. Even if multiparity is incriminated as a factor in the onset of retro-placental hematoma due to vascular fragility due to microangiopathy, as is also found in twin pregnancy and hydramnios [3].

In our series; it occurs regardless of the parity. Retro-placental hematoma most often occurs after high blood pressure in pregnancy [3]. If it is diagnosed and managed correctly, during pregnancy the chance of having RPH decreases. The mean gestational age reported by our study (35.9 AW) was close to those found by Diouf and Hossain, respectively $36 \mathrm{WA}$ and $34 \mathrm{AW}$ [21] [22]. Conjunctival pallor was found in $81.6 \%$ of cases (71/87) in our study. In Togo, Akpadza had a similar result with $76.3 \%$ of cases of paleness of the conjunctiva [8].

In addition, Konaté observed a rate of conjunctival pallor close to the half to the one of our study (43.1\% of cases) [17]. The high rate of conjunctival pallor is thought to be linked to the late diagnosis of retro-placental hematoma. The association of retro-placental hematoma and placenta previa was identified by Akpadza and Konaté in $4.74 \%$ and $17.24 \%$ respectively [8] [17].

We found this association in $5.5 \%$ of cases. This combination often worsens the risk of bleeding. RPH is a life-threatening emergency for both the mother and the fetus if it is still alive. The management depends on the severity of the $\mathrm{RPH}$, the gestational age, the immediate risks (maternal and fetal) and the anticipation of these risks [23]. It should always be remembered that the care must not delay. Vaginal delivery, after direction of labor (in the absence of contraindication), was performed in $51.7 \%$ of cases.

Caesarean section was performed in $48.3 \%$ of cases in our series. Her decision had been made straight away whether the child was alive and whether the vaginal birth had maternal and fetal risks or after a failure of the labor management. The caesarean section rate in our study is within the range of those in the literature [17] [22]. Maternal morbidity was marked by acute anemia of hemorrhagic origin in $81.6 \%$, hypovolemic shock in $44.8 \%$, coagulation disorders which were found in 12 patients $(13.8 \%$ ), acute renal disease in $5.7 \%$ (our results are consistent with the one of Akpadza [8].

The parameters of poor maternal prognosis were afibrinogenemia and the baseline with a statistically significant difference $(\mathrm{p}<0.00)$. Several authors have reported high perinatal mortality rates [6] [8] [21]. In our series, we recorded $69 \%$ of deaths among newborns.

\section{Conclusion}

At the end of this 5-year study on the retro-placental hematoma, in the Department of Gynecology and Obstetrics, it appears that this pathology has a high 
maternal and fetal mortality.

\section{Conflicts of Interest}

The authors declare no conflicts of interest regarding the publication of this paper.

\section{References}

[1] Organisation Mondiale de la Sante (OMS), Bureau Regional de L'Afrique (2004) Prise en charge des complications de la grossesse et de l'accouchement: Guide destiné à la sage-femme et au médecin. 436 p.

[2] Ananth, C.V., Smulian, J.C., Demissie, K., Vintzileos, A.M. and Knuppel, R.A. (2001) Placental Abruption among Singleton and Twin Births in the United States: Risk Factor Profiles. American Journal of Epidemiology, 153, 771-778. https://doi.org/10.1093/aje/153.8.771

[3] Merviel, Ph., Stefanescu, D., Carbillon, L., Mathieu, E., Berkane, N., Uzan, M. and Uzan, S. (2005) Hématome retro-placentaire. In: Cabrol, D., Pons, J.-C. and Goffinet, F., Eds., Traité d Obstétrique, Médecine Sciences Publications, Flammarion, Paris, 916-921.

[4] Bohec, C. and Collet, M. (2010) Hématome rétro-placentaire. Elsevier Masson SAS, Paris, 195-204. https://doi.org/10.1016/B978-2-8101-0152-8.00016-X

[5] Plunkett, J., Borecki, I., Morgan, T., Stamilio, D. and Muglia, L.J. (2008) Population-Based Estimate of Sibling Risk for Preterm Birth, Preterm Premature Rupture of Membranes, Placental Abruption and Pre-Eclampsia. BMC Genetics, 9, 44. https://doi.org/10.1186/1471-2156-9-44

[6] Ananth, C.V., Oyelese, Y., Yeo, L., Pradhan, A. and Vintzileos, A.M. (2005) Placental Abruption in the United States, 1979 through 2001: Temporal Trends and Potential Determinants. American Journal of Obstetrics and Gynecology, 192, 191-198. https://doi.org/10.1016/j.ajog.2004.05.087

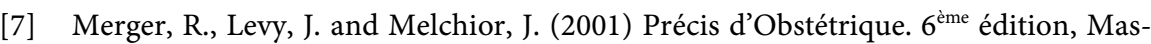
son, Paris, 597 p.

[8] Akpadza, K., Baeta, S., Neglo, Y., Tete, V. and Hodonou, A.K.S. (1996) L’hématome retro-placentaire à la Clinique de Gynécologie-Obstétrique du CHU Tokoin-Lomé (Togo) de 1988 à 1992. Medicale d Afrique Noire, 43, 342-347.

[9] Mounkoro, N., Teguete, I., Traore, Y., Dolo, T., Fomba, A., Traore, M. and Dolo, A. (2008) Hématome retro-placentaire au CHU de GABRIEL TOURE de 2003 à 2007: Fréquence, facteurs de risque et pronostic foto-maternel. Journal des abstracts de communication SAGO, Bamako, 55

[10] Nayama, M., Tamakloe-Azamesu, D., Garba, M., Idi, N., Djibril, B., Kamaye, M., Marafa, A., Toure, A., Diallo, F.Z. and Houfflin-Debarge, V. (2007) Abruptioplacentae. Management in a Reference Nigerien Maternity. Prospective Study about 118 Cases during One Year. Gynécologie Obstétrique \& Fertilité, 35, 975-981. https://doi.org/10.1016/j.gyobfe.2007.05.023

[11] Traore Ndiaye, A., Moreau, J.C., Diouf, F., Faye, E.O., Sepou, A., Bah, M.D. and Diadhiou, F. (1994) Les accidents paroxystiques des syndromes vasculo-rénaux au cours de la gravido-puerpueralité au CHU de Dakar. Dakar Médical, 39, 169-173.

[12] Sepou, A., Ngembi, E., Koyazegbe, T.D., Nbgale, R., Peguele, A., Kouabosso, A. and Yanza, M.C. (2002) Les hémorragies du troisième trimestre de grossesse jusqu'à la 
période de la délivrance. Médecine d' Afrique Noire, 49, 185-189.

[13] Kobelembi, A. (2006) Analyse des urgences obstétricales à l'Hôpital Communautaire de Bangui (République Centrafricaine). Thèse de Doctorat en médecine, Faculté des Sciences de la Santé, Université de Bangui, Bangui, 82 p.

[14] Gothard-Hery, J.-E. (2012) Evolution de la mortalité maternelle à l'Hôpital Communautaire de Bangui: Bilan de 5 ans. Thèse de Doctorat en médecine, Faculté des Sciences de la Santé, Université de Bangui, Bangui, 66 p.

[15] Sepou, A., Goddot, M., Ngbale, R., Brazza-Kokessa, K.Z. and Bangamingo, J.P. (2008) Hémorragies du Post-Partum: A propos de 127 cas à l'Hôpital Communautaire de Bangui. Journal des Abstracts de Communication SAGO, Bamako, 43.

[16] Elmrabet, F., Kharbach, A., Erchidi, I.E., Rhrab, B., Khabouze, S., Ferhati, D., Lakhdar, A. and Chaoui, A. (2002) Hématome rétro-placentaire: Etude rétrospective de 233 cas et Revue de la littérature. JMagh A Réa, 9, 128-131.

[17] Konate, S. (2006) Etude Epidémio-clinique et thérapeutique de l'Hématome retro-placentaire au CHU du Point G et au Centre de référence de la commune $\mathrm{V}$ du District de Bamako (République du Mali). Thèse de doctorat en médecine, Faculté de médecine, de pharmacie et d'odontostomatologie, Université du Mali, 107 p.

[18] Mezane, S., Achnani, M., Ziyadi, M., Babahabib, A., Hafidi, R., Moussaoui, D. and Dehayni, M. (2013) Hématome retro-placentaire et mort fotale in utero: A propos de 49 Cas et revue de la littérature. IJIAS, 3, 570-578.

[19] Foumsou, L., Gabkika, B.M., Saleh, A. and Memadji, M. (2014) Les complications obstétricales chez les adolescentes à la maternité de l'hôpital général de référence nationale (HGRN) de N'Djamena. Médecine d'Afrique Noire, 61, 441-447.

[20] Sepou, A., Yanza, M.C., Domande-Modanga, Z. and Nguembi, E. (2002) Paramètres sexuels chez les femmes centrafricaines en milieu urbain. Medicale $d$ Afrique Noire, 49, 87-91.

[21] Diouf, A.A., Mbaye, M., Diop, A.P., Niang, M.M., Gueye, S.M.K., Diouf, A. and Moreau, J.C. (2014) Prise en charge de l'hématome rétro-placentaire à partir d'une observation de 435 cas au Sénégal: Quelle voie d'accouchement? Médecine d Afrique Noire, 61, 5-10.

[22] Hossain, N., Khan, N., Sultana, S.S. and Khan, N. (2010) Abruptio Placenta and Adverse Pregnancy Outcome. Journal of Pakistan Medical Association, 60, 443-446.

[23] Ananth, C.V. and Kinzler, W.L. (2011) Placental Abruption. In: Sheiner, E., Ed., Bleeding during Pregnancy, Springer, New York, 118-133.

https://doi.org/10.1007/978-1-4419-9810-1_7 